\title{
Transformational Change for Achieving Scale: Lessons for a Greener Recovery
}

\author{
Geeta Batra, Jeneen Garcia, \\ and Kseniya Temnenko
}

\begin{abstract}
Achieving transformational changes that can be then effectively scaled up requires ambition in design, a supportive policy environment, sound project design and implementation, partnerships, and multistakeholder participation. This chapter presents a framework that can be applied at the design stage to plan for change and scaling up and provides relevant lessons based on GEF interventions. Achieving change and scale can be an iterative and a continuous process until impacts are generated at the magnitude and scope of the targeted scale. Successful transformations typically adopt a systems approach and address multiple constraints to attain environmental and other socioeconomic impacts.
\end{abstract}

\section{Introduction}

COVID-19 has transformed our lives in unfathomable ways - it has altered our behaviors, cities, and the environment. It has also affirmed the inextricable link between the broader ecosystem in which we live and human health.

G. Batra $(\bowtie) \cdot$ J. Garcia $\cdot$ K. Temnenko Global Environment Facility Independent Evaluation Office, Washington, DC, USA e-mail: gbatra@thegef.org; Jgarcia2@thegef.org; KTemnenko@thegef.org
Land mismanagement, habitat loss, overexploitation of wildlife, and human-induced climate change have created multiple pathways for pathogens to transmit from wildlife to domestic animals and humans, affecting our health and well-being.

A recent report from the Intergovernmental Science-Policy Platform on Biodiversity and Ecosystem Services (IPBES) concluded that future pandemics will emerge more often, spread more rapidly, kill more people, and impact the global economy more than COVID-19 unless there is a transformative change to address these infectious diseases (Daszak et al., 2020). In fact, the pandemic has made it clear that solutions and future avoidance will require a transformative, systems approach to reduce the global environmental changes caused by unsustainable consumption; these changes drive biodiversity loss; climate change; pollution of oceans, land, and air; and pandemic emergence (Global Environment Facility [GEF], 2020). But the news is not all negative. As pointed out by Professor Klaus Schwab of the World Economic Forum, "The pandemic represents a rare but narrow window of opportunity to reflect, reimagine, and reset our world" (2020, para. 15). It provides a chance to develop an ambitious approach to safeguarding environmental support systems through legal and regulatory instruments, policy measures, capacity building, technological innovations, and scaling-up and replication of 
demonstrated instruments. Monitoring, evaluation, knowledge, and learning activities can play a critical role in assessing progress against initiatives implemented, informing adaptive management, and demonstrating results on environmental outcomes and on socioeconomic benefits generated. Evaluation, while generating lessons for scaling up tested approaches based on prior evidence, is also responding to this call for a systems-based approach to understanding transformation (GEF IEO, 2018; Patton, 2020; Picciotto, 2009, 2020; Uitto, 2019; van den Berg et al., 2019; World Bank Group, Independent Evaluation Group [IEG], 2016).

Addressing the linkages among biodiversity loss, climate change, and emerging diseases is imperative to preventing future pandemics. Globally, there are few funds like the Global Environment Facility, which is positioned to catalyze the transformational change in biodiversity and other environmental areas to reverse the worrisome trends in the global environment. Established in 1992, the GEF is the principal financial mechanism for the Convention on Biological Diversity and an important financial mechanism for the United Nations Framework Convention on Climate Change, the Stockholm Convention on Persistent Organic Pollutants, the United Nations Convention to Combat Desertification, and the Minamata Convention on Mercury. Working through its 18 agencies, the GEF has provided close to $\$ 20$ billion in grants and mobilized an additional $\$ 107$ billion in cofinancing for more than 4,700 projects in 170 countries. The GEF also funds projects in international waters and sustainable forest management that support implementation of global and regional multilateral environmental agreements. Recently, the GEF has promoted multifocal and integrated interventions that interact with broader natural and human systems, with the objective of achieving deep, systemic, and sustainable change with large-scale impact.

Over its nearly 3 decades, the GEF has designed and implemented interventions that have proven to be "transformative," with some pilot initiatives that were subsequently scaled up to achieve results at larger scale. This chapter draws on two recent evaluations investigating transformational change and scaling-up, conducted by the GEF Independent Evaluation Office (IEO), which developed systematic approaches to understand the pathways to transformational change and provide relevant lessons based on GEF interventions.

\section{A Framework for Transformational Change and Achieving Scale}

The GEF IEO evaluation to explore GEF support for transformational change defined such change as: deep, systemic, and sustainable change with large-scale impact in an area of global environmental concern (GEF IEO, 2018). ${ }^{1}$ The underlying theory of change is that by strategically selecting projects that address global environmental concerns and are designed to support fundamental changes in key systems or markets, the GEF engages in interventions that are more likely to lead to a sustainable, large-scale impact, assuming good project design and implementation and supportive contextual conditions. The theory of change is shown in Fig. 1.

For this evaluation, the IEO selected and screened completed GEF projects along the following criteria:

1. Relevance: The intervention addresses a global environmental challenge, such as climate change, biodiversity loss, or land degradation.

2. Depth of change: The intervention causes or supports a fundamental change in a system or market identified as a root cause of an environmental concern.

3. Scale of change: The intervention causes or supports a full-scale impact at the local, national, or multicountry level.

4. Sustainability: The impact of the intervention is financially, economically, environmentally, socially, and politically sustainable in the long term, after the intervention ends.

${ }^{1}$ Evaluation team members: Andres Liebenthal, Geeta Batra, Kseniya Temnenko, Katya Verkhovsky. 
Relevance

- Climate Change

- Biodiversity

- Land Degradation

- Chemicals and Waste

- International Waters

- Sustainable Forest

Management

\section{Internal Factors}

- Quality of implementation

- Quality of execution

- Pre-intervention analytical and advisory activities

- Partnerships with donors

\section{Outcome}

- Depth of change

- Scale of change

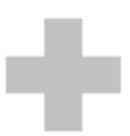

TRANSFORMATIONAL MECHANISM

A mechanism to expand and sustain the impact

of the intervention (through mainstreaming,

demonstration, replication, or catalytic effects)

\section{Ambition level and focus \\ (of intervention \\ objectives) \\ - Depth of change \\ (market and system \\ focus) \\ - Scale of change}

\section{Contextual Conditions}

- Government ownership and support

- Implementation capacity

- Policy environment

- NGO and community participation

- Private sector participation

- Economic and market conditions

\section{Sustainability}

- Financial

- Economic

- Environmental

- Social

- Political

Fig. 1 Theory of Change for GEF Transformational Interventions

Applying qualitative comparative analysis, the evaluation identified drivers of change in deep dives into projects, providing useful lessons for the design and implementation of future interventions (see the Appendix for a table of the projects mentioned in this chapter).

\section{Drivers of Change}

\section{Clear Ambition in Design}

The interventions that achieved transformational change aimed to address fundamental market or systemic distortions as root causes of global environmental concern. The interventions that focused on market transformation targeted the supply and demand of goods and services associated with environmental impacts of global envi- ronmental concern. The cases that aimed at system-wide transformation took a comprehensive approach to modify the functioning of components (economy, public sector, private sector, community) whose collective interaction affect the environment.

\section{Addressing Market and System Reforms Through Policies}

The policy environment had an important impact on the depth and scale of reforms promoted by transformational interventions. All cases addressed market and system changes through policies. Six of the cases helped to strengthen and implement policies to trigger and sustain transformational change, while the two remaining cases leveraged the existing enabling policy frameworks to support transformational change. 


\section{Quality of Project Design and Implementation}

All interventions that achieved transformational change were well implemented in terms of quality of project design and supervision by executing agencies. Some of the salient features across all projects were: comprehensive diagnostic assessments that identified key barriers; coherent designs to address all identified barriers; the early involvement of strong executing agencies that were ready to own the project objectives; and willingness on all sides to learn and adjust the design, scope, and management of the intervention as needed to ensure its success.

\section{Mechanisms for Financial Sustainability}

The transformational interventions established mechanisms for financial sustainability by leveraging market forces and stakeholders' economic interests or by integrating changes within government budgetary systems.

Transformation does not always require large investments. Although major, multiphase, large interventions can support transformational change, relatively modest medium-sized projects, with budgets under $\$ 2$ million, that target main barriers and work with key stakeholders at the right time also can have a significant impact.

\section{Scaling-Up}

Scaling-up is one mechanism for achieving transformational change and one indicator that transformational change is likely to be achieved. We define scaling-up as an increase in the magnitude of global environmental benefits and/or expansion of geographical and sectoral areas covered by those benefits, such as within a specific market or system. The mechanisms for achieving transformational change and scaling-up happen through replication, mainstreaming, linking, or catalytic effects.

Replication refers to the implementation of the same intervention multiple times, thereby increasing the number of stakeholders and/or covering larger areas, by leveraging finance, knowledge, and policy. That is, an intervention may be implemented across a wider area either through government or other funders investing more money for this purpose, through knowledge about the intervention motivating stakeholders to implement using their own resources, through a policy requiring or encouraging stakeholders to implement an intervention, or a combination of these. In the GEF context, countries typically use replication in connection with larger financing and technical assistance provided by the multilateral development banks to reproduce successful interventions on a larger scale.

Mainstreaming involves the integration of an intervention's implementation within an institution's regular operations, usually through a policy or legal framework. While mainstreaming typically happens within a specific national or local government agency, it may also occur simultaneously through multiple government sector agencies, or in other institutions such as donors, civil society organizations, and the private sector.

Linking involves the implementation of multiple types of interventions that, by design, all contribute to the same impact at the scale of a system defined by environmental, economic, or administrative boundaries. The system could be a landscape, seascape, ecoregion, a value chain, supply chain, or a national government. Within value and supply chains, linking takes place between interventions that address causes and effects; for example, through working both in countries where deforestation or wildlife poaching occurs, and countries where demand for the forest and wildlife resources is high. Linking could also involve different interventions under a common theme or transboundary issue, such as water pollution or fisheries. Linking allows for addressing multiple environmental areas in an integrated manner within a specific geographic or ecological unit.

Large-scale catalytic effects are often associated with technological improvements whose benefits can be captured by harnessing an effective market demand. The most notable examples of a catalytic effect involve the transformation of 
the market or system for renewable energy development. With other types of interventions-such as those focused on biodiversity protection and land conservation - the GEF IEO found that the projects' support for cutting-edge science and technologies appeared to have faced greater challenges in capturing and monetizing the related benefits and thereby can rely only partially on market-based approaches.

\section{Factors Influencing Transformative Change and Scaling-Up}

The two GEF IEO evaluations identified internal factors that enable the achievement of transformational results, including:

- Good quality of project implementation that covers the quality of project design and supervision, including a comprehensive diagnostic assessment to identify the barriers that need to be addressed to achieve the objectives of the project

- A careful project design that reflects a coherent logical framework of activities

- A strong implementation agency that is ready to own the objectives of the project and is willing to exert the leadership and acquire the capacity and resources necessary to ensure their achievement

- A willingness to learn, adjust, and adapt the design, scope, and management of the intervention as needed to ensure its success

We found that beneficial pre-intervention analytical activities and contextual conditions include:

- Capacity building

- Building partnerships with international donor partners, which enables projects to expand their scope and scale

- Strong government ownership of and support for the project

- Implementation capacity of local institutions, especially when the activities are spread over a range of sites and local jurisdictions
- Adequacy of the policy environment to create an enabling environment for depth and scale of reforms

- Civil society and local community participation

- Private sector participation; for projects in this evaluation, the impact of private enterprises on the effectiveness of the transformational interventions was mainly defined by the extent of their (supply-side) response to the changes created by the project

- Economic and market conditions

\section{Example 1: Transformative and Effectively Scaled Up: Lighting Africa - Market-Based Solutions for Energy Access}

About 580 million people in Africa have no access to grid electricity and rely on polluting and dangerous sources of lighting such as kerosene lamps, candles, and battery-powered torches. Fuel-based lighting is generally low quality and expensive, which impedes learning and economic productivity.

Modern electric lighting products-such as solar lamps-offer an opportunity for people living in off-grid areas to replace fuel-based lamps with higher quality, safer, cleaner, and more affordable lighting devices. Despite the benefits of solar lamps, the market was not developing as quickly as expected. The market appraisal that was funded by the GEF and the International Finance Corporation/World Bank identified six barriers that inhibited market growth:

1. Consumers did not trust the available solar products because many of them were poorly made and did not work properly.

2. Consumers did not know the benefits of solar lamps, how to use them, or where to buy them. Some consumers were unaware that solar lamps existed.

3. Manufacturers and designers did not know consumer preferences for the design and function of solar lamps. 
4. Supply chain entities did not know each other. Solar lamp manufacturers entering the lowerincome consumer market did not have an established distribution network.

5. Lack of finance was a big problem. Designers and manufacturers, distributors and importers, and retailers needed financing to purchase and move products to the end users. Lowerincome consumers needed microloans to help with the upfront cost of purchasing a solar lamp.

6. Long customs processes and import tariffs on solar lamps were a common concern for manufacturers who considered importing solar lamps to African markets.

The Lighting Africa program was created to transform the off-grid market by removing these barriers. Its goal was to help catalyze markets for quality, affordable, clean, and safe off-grid lighting. The overall approach was to demonstrate the market viability by providing market intelligence; developing a quality assurance infrastructure; facilitating business-to-business interactions; helping governments address policy barriers; providing business development services; and facilitating access to finance for manufacturers, local distributors, and consumers. The program received about $\$ 22$ million in contributions from 2007 to 2013. The GEF was the largest donor, providing more than one third of the funds (World Bank IEG, 2015).

In 2014, the final evaluation of the Lighting Africa program concluded that the program had played a crucial role in transforming the market (Castalia Strategic Advisors, 2014). The key accomplishments as of 2018 are shown in Table 1.

Key factors in Lighting Africa's transformational success included:

- The program operated in areas where there was proven, strong demand for improved offgrid lighting solutions.

- It was carefully designed to simultaneously address all major market barriers. Because barriers differ from market to market, the program started with a basic program design, but
Table 1 Lighting Africa Program Impact as of June 2018

\begin{tabular}{l|l}
\hline Overall Impact \\
\hline $\mathbf{3 2 , 2 8 0 , 2 7 5 1}$ & $\begin{array}{l}\text { People in Africa who are currently } \\
\text { meeting their basic electricity needs } \\
\text { through off-grid solar products meeting } \\
\text { Lighting Global Quality Standards }\end{array}$ \\
\hline $\mathbf{1 7 , 9 2 0 , 9 0 2}$ & $\begin{array}{l}\text { Quality-verified solar lighting } \\
\text { products sold through local } \\
\text { distributorships in Africa since } 2009\end{array}$ \\
\hline $\mathbf{1 , 7 9 2 , 0 9 0}$ & $\begin{array}{l}\text { Metric tons of GHGs avoided in } \\
\text { Africa in the past year; the } \mathrm{CO}_{2}- \\
\text { equivalent of taking 383,745 cars off } \\
\text { the road for a year }\end{array}$ \\
\hline
\end{tabular}

Access to Finance (as of July 2016)

\$20M $\quad$ Foreign exchange credit facility established by the Development Bank of Ethiopia with World Bank funds to support import of qualifying products, including quality-verified solar lanterns

\begin{tabular}{l|l}
\hline $\mathbf{1 , 0 0 0 , 0 0 0}$ & $\begin{array}{l}\text { Ethiopians gained access to modern } \\
\text { energy services through this credit } \\
\text { facility }\end{array}$ \\
\hline $\mathbf{8 0 0 , 0 0 0}$ & $\begin{array}{l}\text { Quality-verified products imported } \\
\text { into Ethiopia through this credit } \\
\text { facility }\end{array}$ \\
\hline $\mathbf{1 1}$ & $\begin{array}{l}\text { MFIs (4 in Kenya, 5 in Ethiopia, 2 in } \\
\text { Nigeria), and KIVA - the crowd- } \\
\text { funding platform, providing consumers } \\
\text { micro-loans for quality-verified, } \\
\text { off-grid lighting and energy products }\end{array}$ \\
\hline
\end{tabular}

\begin{tabular}{l|l}
\hline Market Intelligence (as of January 2018) \\
\hline $\mathbf{3 0}$ & $\begin{array}{l}\text { Market Insight reports published, } \\
\text { facilitating entry into new markets or } \\
\text { mobilization of investors }\end{array}$ \\
\hline $\mathbf{4}$ & $\begin{array}{l}\text { Market Trends reports published, } \\
\text { analyzing the off-grid products market } \\
\text { across Africa, including the 2018 } \\
\text { Global Off-Grid Solar Market Trends } \\
\text { Report }\end{array}$ \\
\hline
\end{tabular}

Quality Standards (as of July 2016)

GLOBAL Lighting Global Quality Standards adopted as international standard for solar lighting products by the International Electrotechnical Commission as IEC Tech Spec 62257-9-5

\begin{tabular}{l|l}
$\mathbf{2 5 5}$ & $\begin{array}{l}\text { Solar lighting and energy products } \\
\text { tested against the Lighting Global } \\
\text { Quality Standards to date }\end{array}$ \\
\hline $\mathbf{1 0 1}$ & $\begin{array}{l}\text { Solar lighting and energy products } \\
\mathbf{( 1 0 W - 1 0 0 W ) ~ c u r r e n t l y ~ m e e t ~ t h e ~} \\
\text { Lighting Global Quality Standards }\end{array}$
\end{tabular}

Partnering with Governments (as of July 2016) (continued) 
Table 1 (continued)

\begin{tabular}{l|l}
\hline Overall Impact \\
\hline $\mathbf{8}$ & $\begin{array}{l}\text { Countries integrated Lighting Africa } \\
\text { activities into their World Bank- } \\
\text { financed energy access projects: } \\
\text { Burkina Faso, Mali, Liberia, DRC, } \\
\text { Uganda, Ethiopia, Tanzania, and } \\
\text { Rwanda. }\end{array}$ \\
\hline Policy (as of July 2016) \\
\hline $\mathbf{3}$ & $\begin{array}{l}\text { National governments (Ethiopia, } \\
\text { Kenya, and Tanzania) and ECOWAS } \\
\text { have or are in the process of adopting } \\
\text { national standards for off-grid solar } \\
\text { products that are harmonized with } \\
\text { Lighting Global Quality Standards }\end{array}$ \\
\hline $\mathbf{1}$ & $\begin{array}{l}\text { Institution, the UN Framework } \\
\text { Convention on Climate Change } \\
\text { (UNFCCC) requires solar lighting } \\
\text { products to meet IEC Technical } \\
\text { Specification 62257-9-5 to qualify for } \\
\text { carbon financing (CDM). }\end{array}$ \\
\hline
\end{tabular}

Source: Lighting Africa (2018)

Note: Lighting Africa has contributed toward these results through its market development activities implemented in collaboration with various intermediaries across the supply chain, development partners, financial institutions, and, most important, manufacturers of solar lighting products and their distribution partners in Africa.

it tailored the components to address the specific barriers identified in the target countries.

- The program focused on market transformation. Lighting Africa did not fund solar lamps-it funded activities that created effective markets in which consumers spent their own money to buy solar lamps.

\section{Example 2: Review, Ownership, and Partnering: Payments for Ecosystem Services in the Danube Basin}

According to the International Commission for the Protection of the Danube River, about $80 \%$ of the historical floodplains in the Danube basin has been lost over the last 150 years. Among the remaining 20\%, the areas along the lower Danube between Bulgaria and Romania and in the Danube delta still possess a rich and unique biological diversity that has been lost in most other European river systems. The International
Commission provides multiple ecosystem services, such as biodiversity conservation, recharging of ground water, water purification, pollution reduction, flood protection, and support for socioeconomic activities such as fisheries and tourism.

The Danube PES project was launched in 2009 with the objective of demonstrating and promoting Payment for Ecosystem Services (PES) and related financing programs in the Danube River basin and other international water basins (Varty, 2012). The project was a GEF medium-size project with total GEF funding of about $\$ 1$ million, cofinancing of $\$ 1.2$ million from the World Wildlife Fund, and in-kind contributions from partners including government agencies, NGOs, local authorities, and private companies. ${ }^{2}$ The project design was focused at the national levels in Bulgaria and Romania, with some outreach activities in Ukraine, Serbia, and the wider Danube river basin. It also included local-level activities where pilot PES programs were to be tested and demonstrated.

Upon completion of the project in 2014, the terminal evaluation concluded that the project had been successful in eliciting the adoption of several national-level PES concepts into national fisheries policies in Romania and Bulgaria, and their testing and implementation in four pilot programs (Stefanova, 2014). Specifically:

- The project designed and introduced a pilot program for the sustainable management and harvesting of biomass (mainly reeds) in Bulgaria's Persina Nature Park, including full cost recovery from the sale of pellets and briquettes.

- Working with the Friends of the Rusenski Lom Nature Park in Bulgaria, the project developed and helped implement a program to generate funds for the protection and maintenance of the aesthetic value and biodiversity of the reserve from the sale of postcards and other promotional materials.

\footnotetext{
${ }^{2}$ The project was also supported by a GEF project preparation grant of $\$ 25,000$.
} 
- The project established a conservation and development fund for Romania's Maramures protected area by attracting sponsorships and donations for local guesthouses and tour operators interested in repositioning the area as an ecotourism destination.

- The project mobilized public funds for the implementation of policies for the maintenance of water quality and biodiversity values in the Ciocanesti area along the lower Danube in Romania. The resulting management practices had led to improved water quality and an observed increase in the number of nesting birds.

Based on the financial, institutional, and sociopolitical support elicited by the project, the evaluation report rated the sustainability of these achievements as moderately likely. Good prospects existed for future financial commitments to sustain the project, but many of these potential resources were still unsecured, especially for the long term. The transformation was modest in scale, focusing on specific target areas within a limited geographic range. As a result of this project, four PES programs in selected wetland areas were established along the lower Danube basin.

The main factors that contributed to the project's success were:

- A timely and effective midterm review found that the project had been too ambitious in relation to its budget and time frame. On this basis, the project followed a recommended streamlining of project objectives, a refocusing on priority areas, and reduction of less important activities.

- The decision to implement the project without direct government involvement allowed the project to proceed at a time when the relevant agencies were overwhelmed with other requirements. These agencies had been involved in the design and development of the project, and actively participated in capacity building and oversight activities, establishing adequate institutional ownership that boded well for the continued adoption, replication, and scaling-up of the piloted approaches.

- The mix of project partners was effective and efficient, with each partner making important contributions toward different aspects. Although the project introduced a very new PES concept, the good collaboration between project partners, driven by their interest in the project, was instrumental in the successful delivery of outcomes.

Not every transformative project is scaled up. Three key actions are necessary for taking impact to scale: (a) adoption of the intervention by relevant stakeholders, (b) sustained support for scaling activities, and (c) learning for adaptability and cost-effectiveness. Figure 2 includes the factors and enabling conditions that influence these three actions.

\section{Adoption of the Intervention}

Relevant stakeholders must first be willing to implement the intervention that generates impact.

Factors that contributed to stakeholders' willingness to adopt an intervention clustered into two types: those that developed a sense of ownership for the intervention, and those that made the benefits of adopting the intervention clear and salient.

Stakeholder ownership has been identified in several IEO evaluations as a key contributing factor to progress toward impact. Having ownership implies that stakeholders find a program's objectives meaningful and useful to themselves personally. Buy-in to the intervention is attributed at least in part to participatory activities or mechanisms (Garcia, 2019), such as public consultations during project preparation, village committees, and community-based natural resource management agreements.

Stakeholders are motivated to adopt the intervention because they perceive the benefits of doing so. Benefits are defined as gains or avoided losses. Gains are usually noted in the form of 


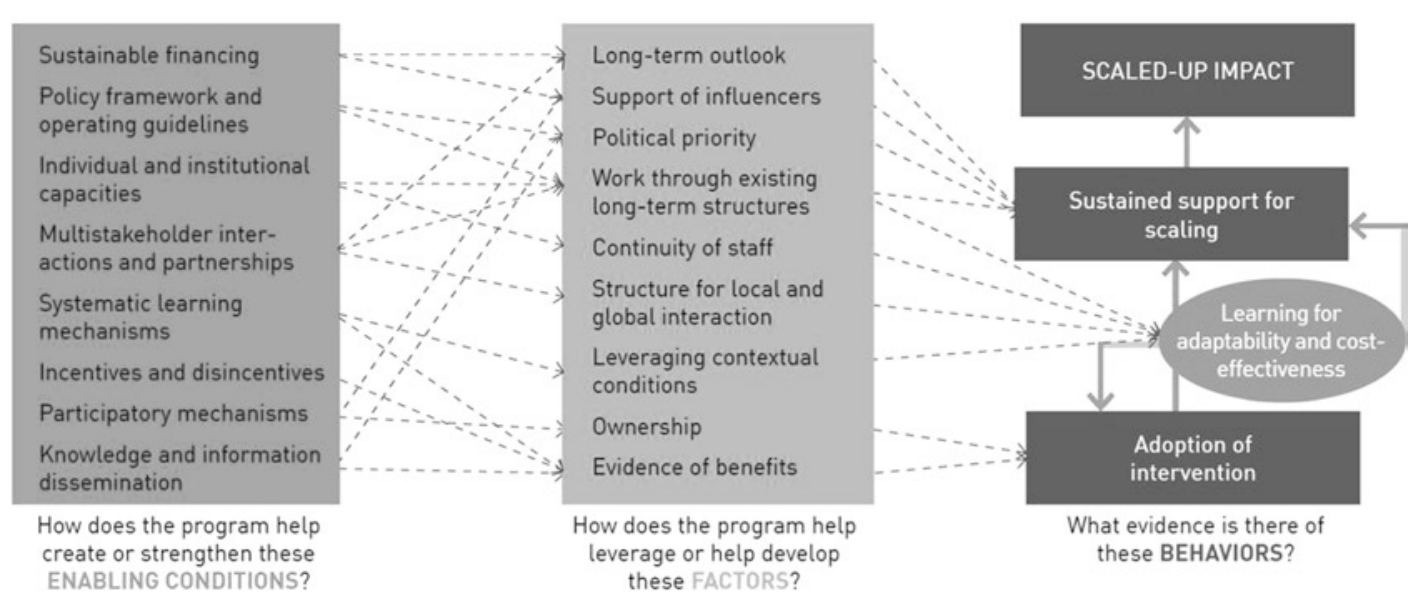

Fig. 2 Framework for Assessing the Likelihood of Scaling-Up. (Adapted from GEF IEO (2019))

higher income, cost savings, or new business opportunities; losses avoided are usually in the form of penalties, legal liabilities, or decreasing income due to a degraded natural resource base.

In some cases, adopting an intervention had the synergistic effect of both creating gains and avoiding losses. For example, in Macedonia, a cheaper alternative for PCB decontamination together with the risk of penalties for noncompliance created mutual reinforcement for private companies to decontaminate their equipment. Similarly, when farmers in China and Brazil switched to sustainable land management (Garcia, 2018), it resulted in both biodiversity protection and higher incomes, among other benefits (see project list in Appendix).

Pilot activities are sometimes not successfully scaled up because the gains are not sufficient to overcome the costs of changing the status quo. For example, a GEF project introduced the planting of buffer strips and pasture rehabilitation as part of managing nutrient pollution in the Danube River. The pilot was successful, yet did not scale in a subsequent project, in part due to state subsidies that left little incentive to include forestry activities in land management. Other components of the project that demonstrated benefits, such as reduced manure in waterways, were successfully scaled up and continue to expand without GEF support.

\section{Sustained Support for Scaling-Up Processes}

For the relevant stakeholders to implement the intervention that generates impact, supporting institutions must sustain the enabling conditions for implementation.

All successful cases of scaling-up received some form of support for longer than a typical 5 -year project, mainly from their respective governments. This evaluation and other research have found that, in general, sustained support of between 10 and 20 years is necessary for scalingup to take place.

Three factors emerged as important for ensuring long-term support for scaling-up processes: (a) scaling-up becoming a political priority, (b) gaining the support of political and economic influencers, and (c) working through existing long-term structures that depend on the appropriate choice of partner institutions.

Figure 2 highlights the necessary conditions for enabling scaling-up. First, knowledge and information dissemination, participatory processes, and incentives and disincentives are needed to motivate adoption of interventions. Second, strong institutional and individual capacities, policy framework and operating guidelines, and sustainable financing provide 
the resources for sustained implementation. Finally, multistakeholder interactions and partnerships and systematic learning mechanisms allow the scaling-up process to be adaptable and cost effective in the face of changing contextual conditions.

A program can support the establishment and strengthening of these enabling conditions, which can increase not just the implementation of an intervention by relevant stakeholders, but also support for scaling-up activities from institutions, in a positively reinforcing cycle. In Brazil, the GEF invested very early on in establishing FUNBIO (https://www.funbio.org.br/), ${ }^{3}$ an organization that is now implementing scaling-up activities in the Amazon protected areas under a government mandate.

\section{Learning for Adaptability and Cost-Effectiveness}

For scaling-up processes to be sustained, supporting institutions have to learn from systematic feedback that will allow them to adapt the scaling-up process to changing contexts and make it more cost effective.

Project evaluations at midterm and closure have contributed to the scaling-up process. In many of the GEF projects we explored, learning from these evaluations typically led to reallocation of project funds. For example, in the case of Romania, the reallocation led to a shift from an expensive, concrete-based agricultural waste management platform to a cheaper and equally efficient plastic alternative, allowing more farmers to benefit from the funds. In China's termite control initiative, the learning resulted in a decision to use a more cost-effective form of integrated pest management. The

${ }^{3}$ This took place in 1991 through the Brazilian Biodiversity Fund project. cost savings were reallocated toward additional technical training and public awareness-raising activities. Systematic learning mechanisms were usually in the form of knowledge exchange networks and regular multistakeholder meetings.

A few cases integrated adaptability into project design by allowing flexibility about which interventions to adopt and scale up based on actual contextual conditions. For example, throughout the implementation of the Rural Electrification and Renewable Energy Development project in Bangladesh, the project continuously incorporated lessons from its own pilot approaches, and-as the national demand for the solar home systems grew-the project shifted its focus to this component. The project also utilized monitoring and evaluation data from the field to incorporate new features such as LEDs to better serve lower income households, which in turn made the solar home systems more attractive to a larger population.

\section{Conclusions}

Achieving transformational changes that can be then effectively scaled up requires ambition in design, a supportive policy environment, sound project design and implementation, partnerships, and multistakeholder participation. This chapter presents a framework that can be applied at the design stage to plan for change and scaling-up and provides relevant lessons based on GEF interventions. Achieving change and scale can be an iterative and a continuous process until impacts are generated at the magnitude and scope of the targeted scale. Successful transformations typically adopt a systems approach and address multiple constraints to attain environmental and other socioeconomic impacts. 


\section{Appendix}

\section{Projects Discussed in This Chapter}

\begin{tabular}{|c|c|c|c|c|}
\hline Name & GEF ID & Implementing Agency & Country & $\begin{array}{l}\text { Relevant Case } \\
\text { Study }\end{array}$ \\
\hline $\begin{array}{l}\text { Rural Electrification and Renewable Energy } \\
\text { Development }\end{array}$ & 1209 & The World Bank & Bangladesh & $\begin{array}{l}\text { Bangladesh } \\
\text { RERED }\end{array}$ \\
\hline $\begin{array}{l}\text { Rio de Janeiro Integrated Ecosystem } \\
\text { Management in Production Landscapes of the } \\
\text { North-Northwestern Fluminense }\end{array}$ & 1544 & The World Bank & Brazil & $\begin{array}{l}\text { Brazil Rio } \\
\text { Rural case }\end{array}$ \\
\hline $\begin{array}{l}\text { PRC-GEF Partnership: Land Degradation in } \\
\text { Dryland Ecosystems: Project I-Capacity } \\
\text { Building to Combat Land Degradation }\end{array}$ & 956 & $\begin{array}{l}\text { Asian Development } \\
\text { Bank }\end{array}$ & China & China IEM case \\
\hline $\begin{array}{l}\text { PRC-GEF Partnership: An IEM Approach to } \\
\text { the Conservation of Biodiversity in Dryland } \\
\text { Ecosystems - under the PRC-GEF Partnership } \\
\text { on Land Degradation in Dryland Ecosystem } \\
\text { Program }\end{array}$ & 2369 & $\begin{array}{l}\text { International Fund } \\
\text { for Agricultural } \\
\text { Development }\end{array}$ & China & China IEM case \\
\hline $\begin{array}{l}\text { PRC-GEF Partnership: Forestry and } \\
\text { Ecological Restoration in Three Northwest } \\
\text { Provinces (formerly Silk Road Ecosystem } \\
\text { Restoration Project) }\end{array}$ & 3483 & $\begin{array}{l}\text { Asian Development } \\
\text { Bank }\end{array}$ & China & China IEM case \\
\hline $\begin{array}{l}\text { PRC-GEF Partnership: Capacity and } \\
\text { Management Support for Combating Land } \\
\text { Degradation in Dryland Ecosystems }\end{array}$ & 3484 & $\begin{array}{l}\text { Asian Development } \\
\text { Bank }\end{array}$ & China & China IEM case \\
\hline $\begin{array}{l}\text { PRC-GEF Partnership: Sustainable } \\
\text { Development in Poor Rural Areas }\end{array}$ & 3608 & The World Bank & China & China IEM case \\
\hline $\begin{array}{l}\text { PRC-GEF Partnership: Mainstreaming } \\
\text { Biodiversity Protection within the Production } \\
\text { Landscapes and Protected Areas of the Lake } \\
\text { Aibi Basin }\end{array}$ & 3611 & The World Bank & China & China IEM case \\
\hline $\begin{array}{l}\text { Demonstration of Alternatives to Chlordane } \\
\text { and Mirex in Termite Control }\end{array}$ & 2359 & The World Bank & China & $\begin{array}{l}\text { China termite } \\
\text { control initiative }\end{array}$ \\
\hline $\begin{array}{l}\text { Promoting Payments for Environmental } \\
\text { Services (PES) and Related Sustainable } \\
\text { Financing Schemes in the Danube Basin }\end{array}$ & 2806 & UNEP & $\begin{array}{l}\text { Regional: } \\
\text { Bulgaria, } \\
\text { Romania }\end{array}$ & $\begin{array}{l}\text { Danube PES } \\
\text { Project }\end{array}$ \\
\hline $\begin{array}{l}\text { Lighting Africa/Lighting "The Bottom of the } \\
\text { Pyramid" }\end{array}$ & 2950 & The World Bank & $\begin{array}{l}\text { Regional: } \\
\text { Ghana, Kenya }\end{array}$ & Lighting Africa \\
\hline $\begin{array}{l}\text { Enabling Activities to Facilitate Early Action } \\
\text { on the Implementation of the Stockholm } \\
\text { Convention on Persistent Organic Pollutants } \\
\text { (POPs) in the Republic of Macedonia }\end{array}$ & 1518 & $\begin{array}{l}\text { United Nations } \\
\text { Industrial } \\
\text { Development } \\
\text { Organization }\end{array}$ & $\begin{array}{l}\text { North } \\
\text { Macedonia }\end{array}$ & $\begin{array}{l}\text { Macedonia PCB } \\
\text { case }\end{array}$ \\
\hline $\begin{array}{l}\text { Demonstration project for Phasing-out and } \\
\text { Elimination of PCBs and PCB-Containing } \\
\text { Equipment }\end{array}$ & 2875 & $\begin{array}{l}\text { United Nations } \\
\text { Industrial } \\
\text { Development } \\
\text { Organization }\end{array}$ & $\begin{array}{l}\text { North } \\
\text { Macedonia }\end{array}$ & $\begin{array}{l}\text { Macedonia PCB } \\
\text { case }\end{array}$ \\
\hline $\begin{array}{l}\text { DBSB: Agricultural Pollution Control } \\
\text { Project - under WB-GEF Strategic Partnership } \\
\text { for Nutrient Reduction in the Danube River } \\
\text { and Black Sea }\end{array}$ & 1159 & The World Bank & Romania & $\begin{array}{l}\text { Romania } \\
\text { international } \\
\text { waters case }\end{array}$ \\
\hline $\begin{array}{l}\text { DBSB: Integrated Nutrient Pollution Control } \\
\text { Project-under the WB-GEF Investment Fund } \\
\text { for Nutrient Reduction in the Danube River } \\
\text { and Black Sea }\end{array}$ & 2970 & The World Bank & Romania & $\begin{array}{l}\text { Romania } \\
\text { international } \\
\text { waters case }\end{array}$ \\
\hline Brazilian Biodiversity Fund & 126 & The World Bank & Brazil & $\mathrm{n} / \mathrm{a}$ \\
\hline
\end{tabular}




\section{References}

Castalia Strategic Advisors. (2014). Evaluation of lighting Africa program - Final report. Report to International Finance Corporation.

Daszak, P., das Neves, C., Amuasi, J., Hayman, D., Kuiken, T., Roche, B., Zambrana-Torrelio, C., Buss, P., Dundarova, H., Feferholtz, Y., Foldvari, G., Igbinosa, E., Junglen, S., Liu, Q., Suzan, G., Uhart, M., Wannous, C., Woolaston, K., Mosig Reidl, P., ... Ngo, H. T. (2020). Workshop report on biodiversity and pandemics of the Intergovernmental Platform on Biodiversity and Ecosystem Services. IPBES Secretariat. https://doi.org/10.5281/zenodo.4147317

Garcia, J. (2018). You win some, you lose some Synergies and trade-offs of GEF support (Part 1). https://eartheval.org/blog/you-win-some-you-losesome-\%E2\%80\%93-synergies-and-trade-offs-gefsupport-part-1

Garcia, J. (2019). Want to scale up? Change-proof your program! Lessons from the GEF (Part 1). https:// eartheval.org/blog/want-scale-change-proof-yourprogram-lessons-gef-part-1

Global Environment Facility. (2020). White paper on a GEF COVID-19 response strategy: The complexities and imperatives of building back better. https:// www.thegef.org/sites/default/files/council-meetingdocuments/EN_GEF_C.59_Inf.14_White\%20 Paper\%20on\% 20a\%20GEF\% 20COVID-19\%20 Response\%20Strategy_.pdf

Global Environment Facility Independent Evaluation Office. (2018). Evaluation of GEF support for transformational change. https://www. gefieo.org/evaluations/evaluation-gef-supporttransformational-change-2017

Global Environment Facility Independent Evaluation Office. (2019). Evaluation of GEF support to scaling up impact 2019. http://www.gefieo.org/evaluations/ evaluation-gef-support-scaling-impact-2019

Lighting Africa. (2018). Program impact as of June 2018. https://www.lightingafrica.org/about/our-impact/

Patton, M. Q. (2020). Evaluation criteria for evaluating transformation: Implications for the coronavirus pandemic and the climate emergency.
American Journal of Evaluation. https://doi. org/10.1177/1098214020933689

Picciotto, R. (2009). Development effectiveness: An evaluation perspective. In G. Mavrotas \& M. McGillivray (Eds.), Development aid: Studies in development economics and policy (pp. 180-210). Palgrave Macmillan. https://doi.org/10.1057/9780230595163_8

Picciotto, R. (2020). From disenchantment to renewal. Evaluation, 26(1), 49-60. https://doi. org/10.1177/1356389019897696

Schwab, K. (2020, June 3). Now is the time for a 'great reset'. World Economic Forum. https://www.weforum.org/agenda/2020/06/ now-is-the-time-for-a-great-reset/

Stefanova, V. (2014). Terminal evaluation of the project Promoting payments for ecosystem services $(P E S)$ and related sustainable financing scheme in the Danube Basin. United Nations Environment Programme, Evaluation Office. http://hdl.handle. net/20.500.11822/244

Uitto, J. I. (2019). Sustainable development evaluation: Understanding the nexus of natural and human systems. New Directions for Evaluation, 2019(162), 49-67. https://doi.org/10.1002/ev.20364

van den Berg, R. D., Magro, C., \& Salinas Mulder, S. (Eds.). (2019). Evaluation for transformational change: Opportunities and challenges for the Sustainable Development Goals. International Development Evaluation Association. https://ideasglobal.org/transformational-evaluation/

Varty, N. (2012). Promoting payments for ecosystem services (PES) and related sustainable financing schemes in the Danube Basin. Mid-Term Review. Final Report. United Nations Environment Programme, Evaluation Office.

World Bank Group, Independent Evaluation Group. (2015). World Bank Group support to electricity access, FY2000-2014. World Bank. https://ieg. worldbankgroup.org/sites/default/files/Data/reports/ ElectricityAcces_v2.pdf

World Bank Group, Independent Evaluation Group. (2016). Supporting transformational change for poverty reduction and shared prosperity: Lessons from the world bank experience. World Bank. https://openknowledge.worldbank.org/handle/10986/24024

Open Access This chapter is licensed under the terms of the Creative Commons Attribution 4.0 International License (http://creativecommons.org/licenses/by/4.0/), which permits use, sharing, adaptation, distribution and reproduction in any medium or format, as long as you give appropriate credit to the original author(s) and the source, provide a link to the Creative Commons license and indicate if changes were made.

The images or other third party material in this chapter are included in the chapter's Creative Commons license, unless indicated otherwise in a credit line to the material. If material is not included in the chapter's Creative Commons license and your intended use is not permitted by statutory regulation or exceeds the permitted use, you will need to obtain permission directly from the copyright holder.

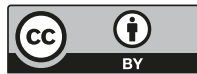

